\title{
Management Information Systems on Integrated Student and Lecturer Data
}

\author{
Penny Hendriyati ${ }^{1}$, Farida Agustin ${ }^{2}$, Untung Rahardja ${ }^{3}$, Tarisya Ramadhan ${ }^{4}$ \\ 'STTIKOM Insan Unggul \\ 2Sekolah Tinggi Ilmu Ekonomi Al - Khairiyah \\ 3,4 University of Raharja \\ e-mail: pennyhendriyati@gmail.com ${ }^{1}$,_agustin.farida71@gmail.com ${ }^{2}$,untung@raharja.info ${ }^{3}$, \\ tarisya@raharja.info ${ }^{4}$
}

To cite this document :

Hendriyati, P., Farida, A., Rahardja, U., \& Ramadhan, T. (2022). Management Information Systems on Integrated Student and Lecturer Data. Aptisi Transactions on Management (ATM), 6(1), 1-9.

DOI :

https://doi.org/10.33050/atm.v6i1.1527

\begin{abstract}
One of the most important things in higher education is the development of an integrated information system and data management, this is important because of the high need and completeness of attributes for each component related to the academic field in all tertiary institutions. Systems with different levels of functionality run independently of one another, causing many problems for the school's IT system as a whole. Primary data in the academic field are students and lecturers. Many difficulties arise from consistently unregistered data, duplicate manual data entry, the extra time it takes to manage multiple user accounts for a single user, and non-productive time spent on technical support. Apart from these problems, the task of maintaining each individual system is time consuming. The challenges described above have driven this research study. Data management and governance are well maintained so that the delivery of information is accurate, transparent, accountable and up-to-date. Lecturers and students can apply research methods with the SDLC model to produce a system that will later repair or replace the old system, through the design and implementation of a data management information system. In implementing policies for lecturers and students, this information system will provide formulations and descriptions to the leadership.
\end{abstract}

Keywords: Information Systems Management, SDLC, Academic

\section{Introduction}

Basically technology has a benefit in the management system in a college, which has an important role in data management data by using technology and then producing information that is useful for the community and institutions [1]. By using this technology, governance aims to produce transparent and accurate information and work professionally [2]. One of the universities established in 2013 and located in riau province Singingi district is one of the only universities in this district [3]. This college is relatively new, so many things must be improved in the management and governance data in universities, one of which is the information system of data management of lecturers and students, so that it becomes a college that has a quality level of management and accurate data [4][5]. Primary data of lecturers and students owned by universities must be accurate and accurate [6]. With the attributes of complete data f rom students and lecturers, making university institutions must minimize problems that will arise later, such as incomplete data, difficulty in $f$ inding the desired data, confusion arising in the data, and other problems [7]. In universities, a system is needed that is designed to use a programming language in order to create good data management in an institution [8][9], so as to be able to present information about student and lecturer data appropriately and avoid problems that can hinder the 
effectiveness of performance and the Deans and Chairmen of the Study Program can know the biodata and number of students and in reporting student and lecturer data to college leaders facilitate in the system of facilitating administrators [10][11].

\section{Literature Review}

\section{A. Information Systems}

The f ramework can be an arrangement of interconnected methods, gathered together to perform a movement with the aim of achieving a specific goal. A f ramework consists of a number of interconnected components, which means working together as a whole [12]. In other words, the system can be a collection of related components to realize a specific goal. Dat a is data that is handled into a f rame that is more valuable and more important to those who get it [13].Data sources derived f rom System Information Can still be an arrangement of interconnected procedures, put together to perform a movement with the intention of achieving a certain goal. The $f$ ramework consists of a number of association components, which suggest cooperation to create a single unit. In other words the f ramework can be a collection of related components to realize a specific goal [14]. Data is information that is handled into a f rame that is more valuable and more important to those who get it. The data source comes $\mathrm{f}$ rom information that is a reality that describes an event and the original unit [15]. The system can be a collection of coordinate components to realize a specific purpose while the data is information that has been prepared into a form that is more important to the recipient and valuable in making current or future choices. Data can describe broadcast events used for decision making. Data sources are information that can be letter $f$ rames, images, letter sets and so on [16]. The Essential Performance System is input, handling, and use [17]. Data handling functions often require information that has been collected and handled in the previous period. Therefore, the display of the data f ramework is also included in the information capacity media (database) so that the data preparation work does not convert the information into data but more than it stores information to help with utilization [18][19].

\section{B. Information Integration}

Information Integration What is information integration is a way of combining or entering information $f$ rom various sources and supporting clients to see the solidarity of information [20]. The holding of these mergers can occur in various forms of institution trading, whether commercial (exemplified when two commercial educations will consolidate. or a combination of them, such as banks and others) or non-commercial (instructive education, clinics, etc.) [21]. Data integration is needed in addition to organizational improvements and increased forms of trade in these institutions that generally require information and data $f$ rom divisions or units within the organization [22]. To be able to carry out the preparation of information integration, the most important thing to note is how the ascension component between forms of trade in each unit or division in the organization [5]. Of course, approval on the integration instruments of the trading handle is required by the administration of these units which allows affecting what information will be traded to meet the trading needs of each unit [23].

\section{Research Method}

In another sense, SDLC can be a work system that aims to provide a high quality system in understanding the client's wishes or reasons [24]. Framework. SDLC can be a system that contains steps that must be taken to prepare for the progress of a program. This $f$ ramework contains all the settings for creating, maintaining, and replacing specific computer programs. The author uses the SDLC (software Development Life Cycle) model as a reference, considering that the SDLC model is a lay methodology in the cycle of system development and means the preparation of a new system to replace an outdated system using or repairing an existing system [25]. 


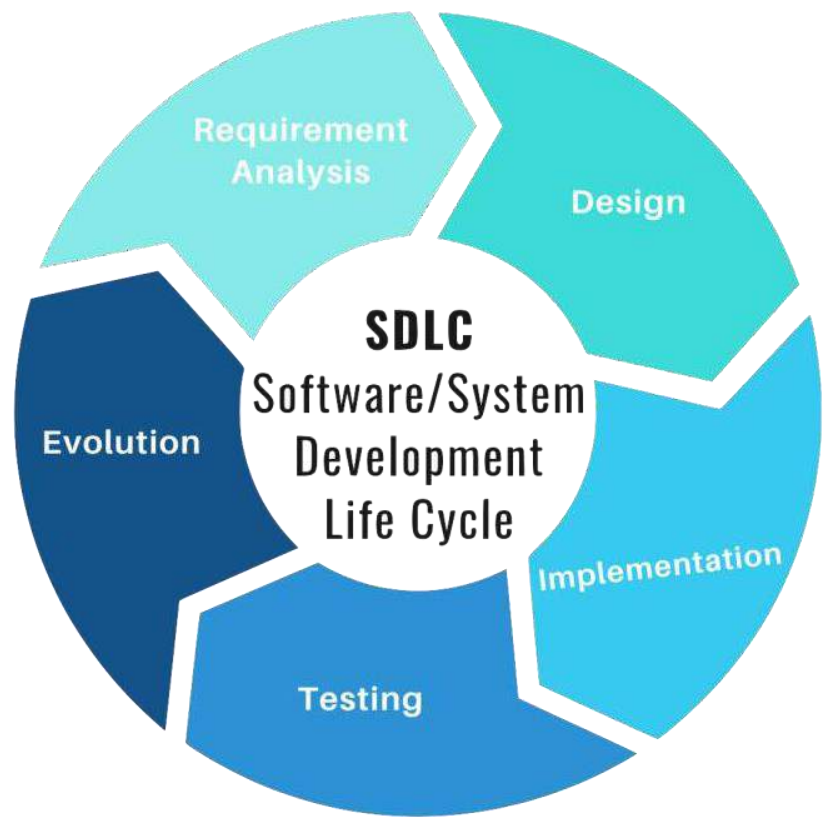

Figure 1. SDLC Model

SDLC may be a cycle used in the creation or improvement of data systems aimed at properlyexplaining problems.

\subsection{Research Design}

This research is designed through several stages or procedures, as follows:

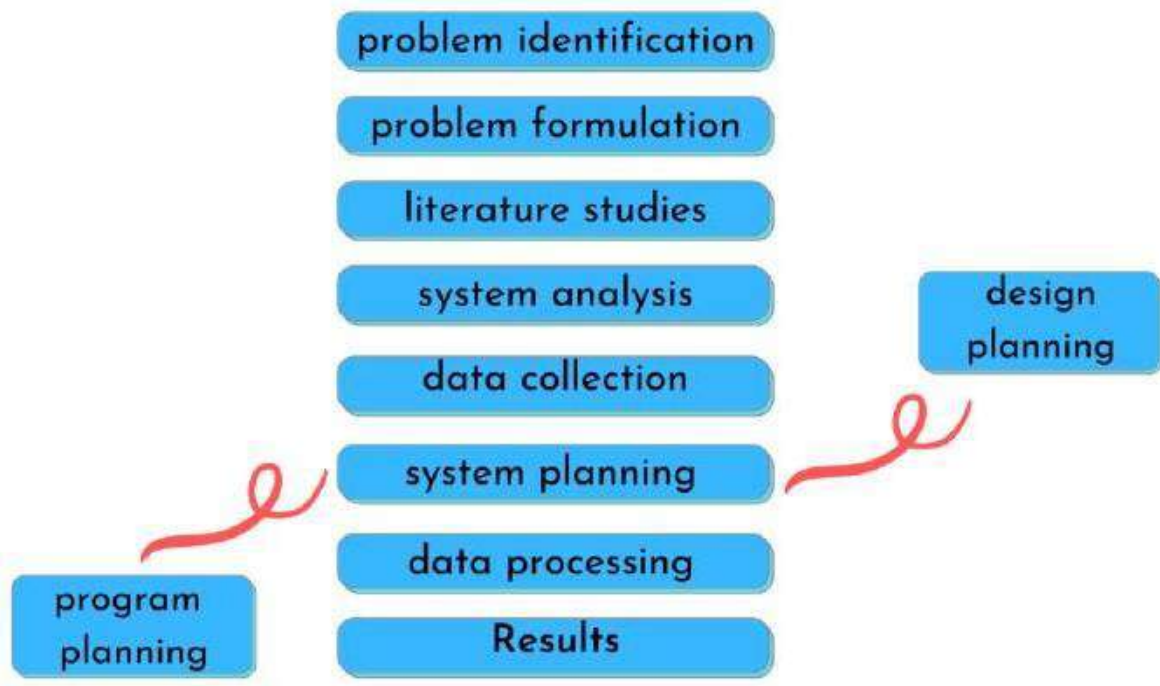

Figure 2. Research Stages

Figure 2 shows the stages of research consisting of problem identification, problem formulation, literature studies, system analysis, data collection, system planning, data processing and results [26]. 


\subsection{Data Collection Techniques}

One of the crucial factors in the development of the info system is understanding the existing system and its problems [27]. As for the concrete description of the techniques

Data Collection

A crucial factor in the development of gossip systems is understanding the existing system and its problems [28]. The concrete description of the origin of this research data collection technique will be described as follows [29]:

\section{- $\quad$ Literature Studies}

Literature studies are conducted in order to receive data that is theoretical, then use that the author to collect data using a way of reading and studying li terature similar to books, papers or other relevant references using the issues discussed [30].

\section{- Interview Techniques}

The $f$ irst step that must be done in the process of building and developing information systems is to identify the needs of the system, analyze the existing situation and $f$ ind real problems and simultaneously connect them with the causes of the problem. The Interview Technique is one of the best ways that can be used for this activity [31].

\section{- Observation Techniques}

Personal observation or observation is a technique of collecting data by exclusively looking at the activities carried out by the user. This one-profit error of personal observation/observation means that the analysis system can be more familiar with the physical environment [32].

\section{Results and Analysis}

System analysis and data collection conducted, data collection of Students and Lecturers through the publishing system is able to help admin coordinators, leaders and study programs in obtaining careful data.

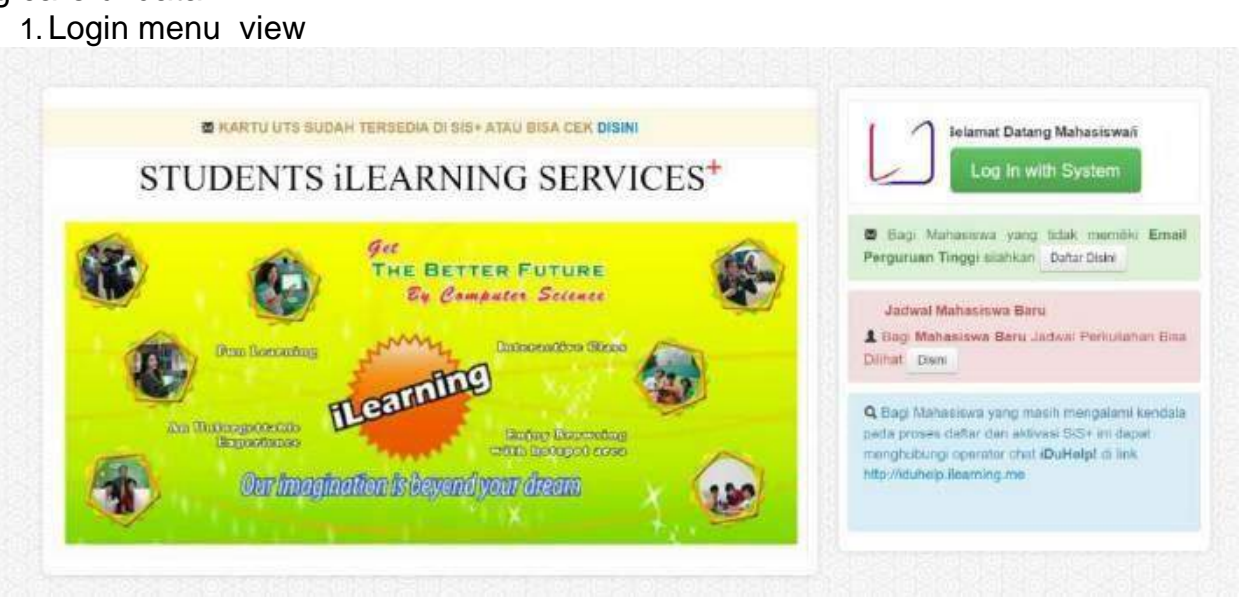

Figure 3. Login menu view.

Figure 3 Is a view of the login menu used to login as students and lecturers. 
2. Dashboard of the beginning of login to inform student/lecturer data information

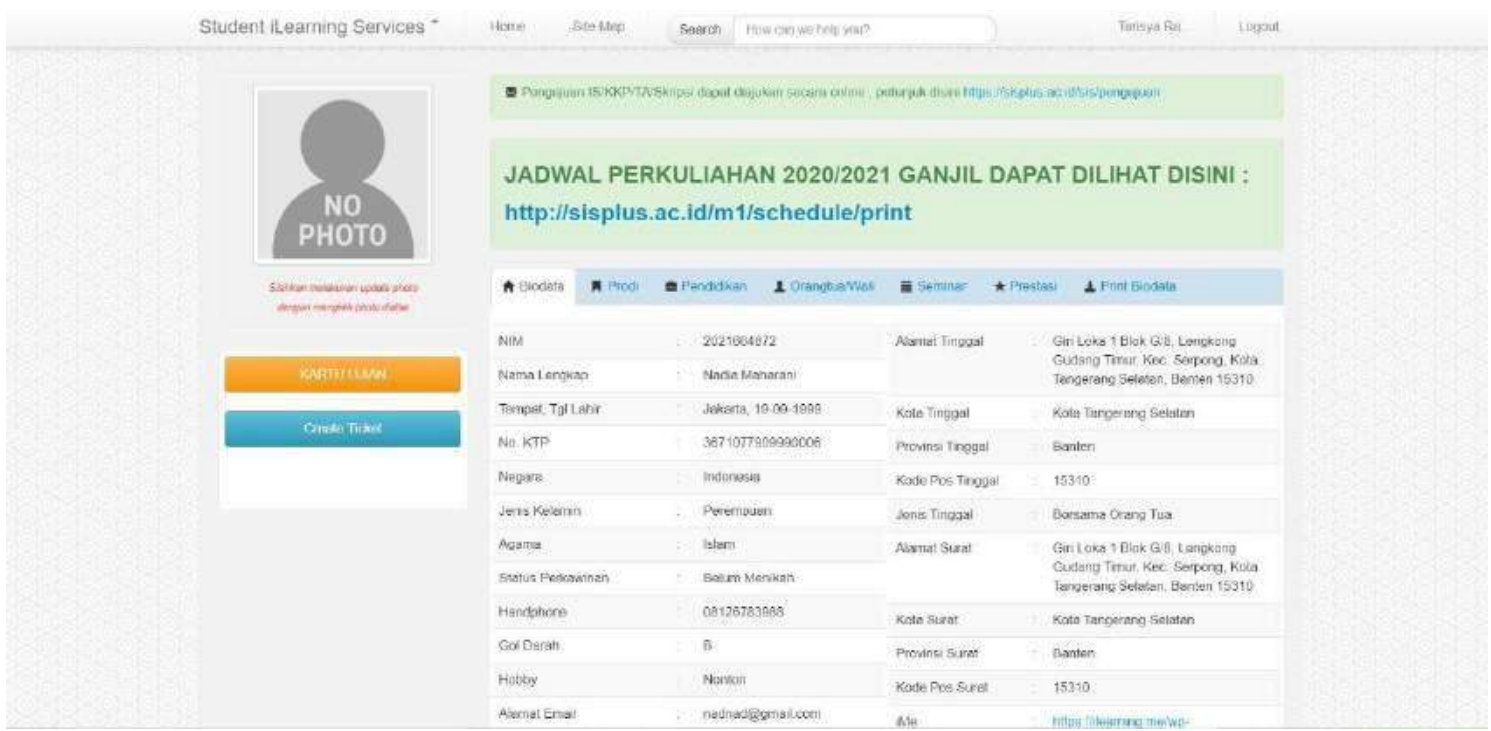

Figure 4. Initial dashboard

Figure 4 is the initial dashboard of the login to inform the student/lecturer data information .

3.Student Guidance Card Menu

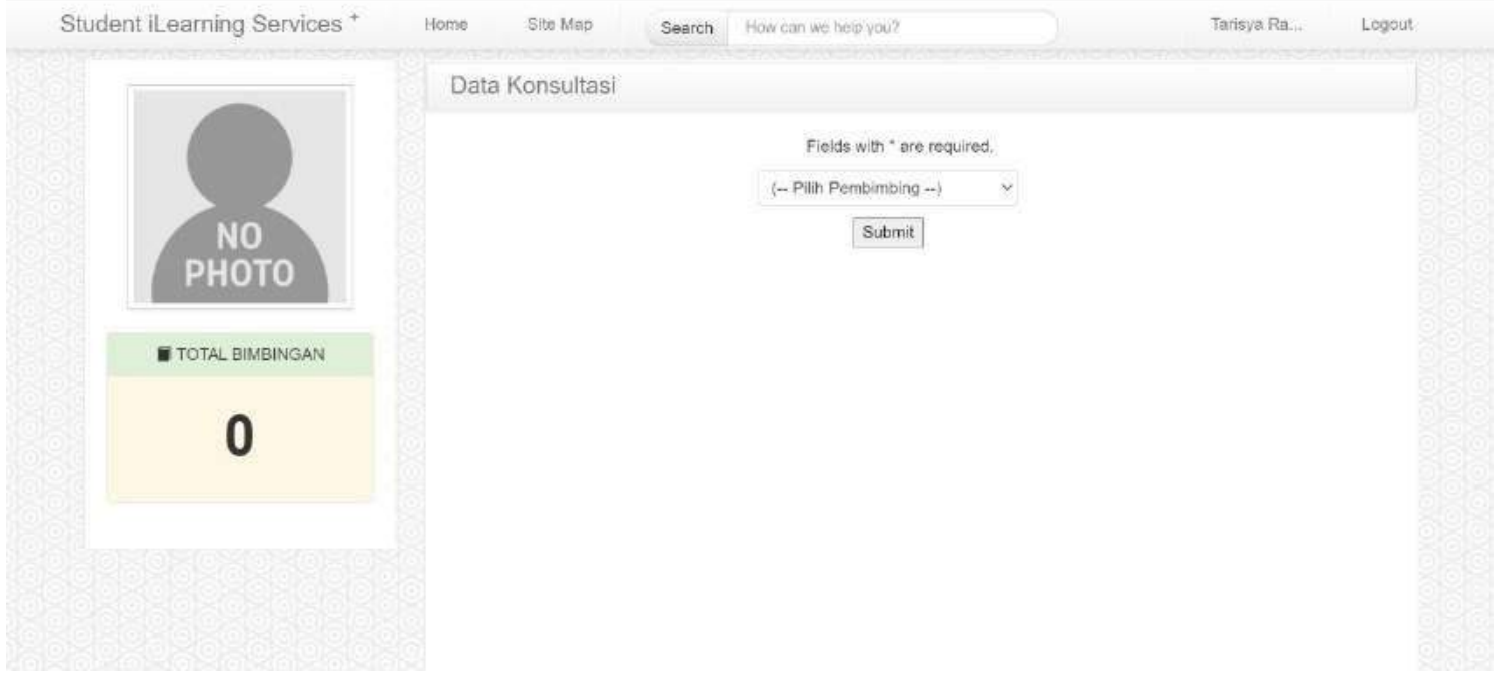

Figure 5. Student guidance card menu

The guidance card menu shows the data of student consultation with lecturers and how many students have guidance to lecturers . 
4 Menu Entry student data

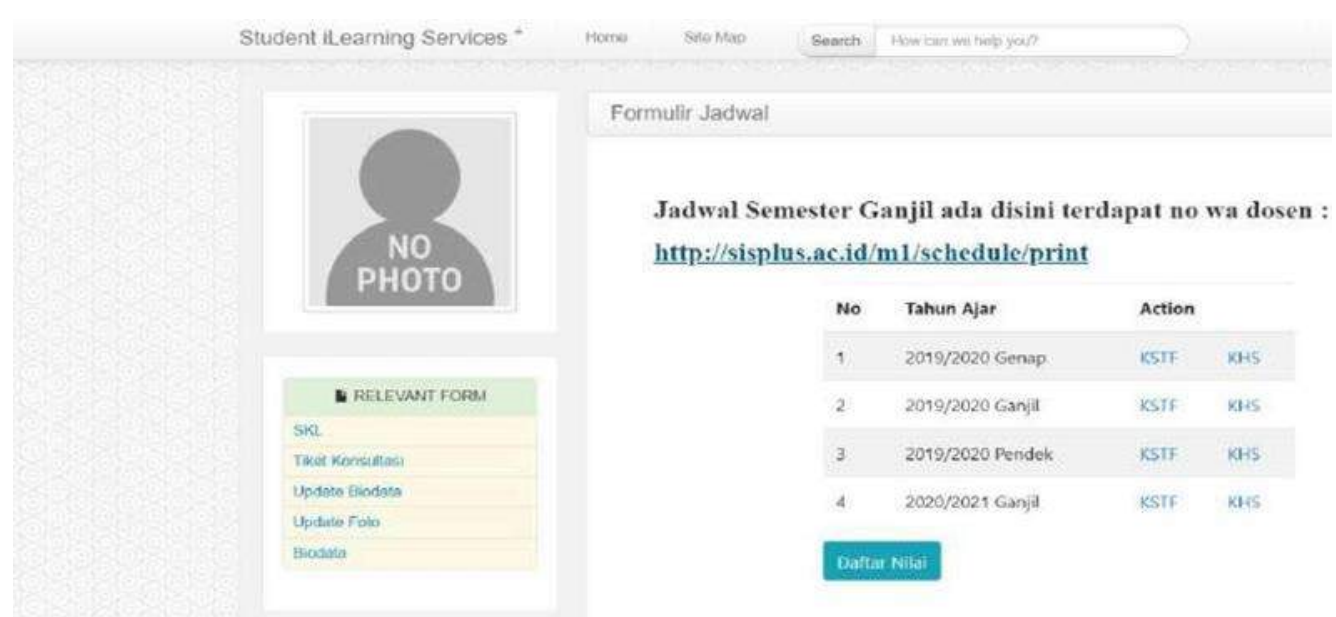

Figure 6. Entry menu student schedule

Figure 6 is the Entry Menu for data showing the integration of information to show the student's own semester schedule.

\section{Conclusion}

The aim of this study was to examine Student Information Systems at several charter schools in southeastern Michigan and northeastern Ohio, and to create IT solutions that would solve many of the problems endemic in today's systems. Several major problems with the current system were identified, and suggestions and changes for a better and more efficient system emerged.

The main result is an integrated system which eliminates the need for multiple payment systems causing difficulties and inefficiencies for the school system involved. The redesigned system allows all stakeholders to enter and access the Student Information S ystem, File Management System, Learning Management System, and Content Management System. New technologies available for web application development are identified and adopted into redesigned solutions. Using open source Web 2.0 technology to integrate four different systems into one system allows users to access all school systems and services with one step entry. The proposed system described in this paper will be further developed by taking the next steps and implementing the prototype into the system directly in the schools participating in the study. 


\section{Advice}

Based on the above conclusions, the author provides several proposals so that the Framework of Coordinates Scholastic Data in Universities can run well, as for the proposals submitted by the creators as follows:

A. There must be changes to the integration $f$ ramework that combines the Unused Understanding Registration Data Framework, the Understanding Installment Data Framework and the Scientific Data Framework so that the integration of the three f rameworks can run well and can have a great inf luence on learning exercises in universities.

B. It is important to hold regulatory support which is a way of communication of information from the integration of $f$ rameworks.

$\mathrm{C}$. The creator realizes that this research is far $\mathrm{f}$ rom the top, the author believes that this research can be created and refined in order to be more idealized. 


\section{REFERENCES}

[1] [1] C. Lukita, "Penerapan Sistem Pendataan Hak Cipta Content Menggunakan Blockchain,"

ADI Bisnis Digit. Interdisiplin J., vol. 1, no. 2, pp. 40-45, 2020.

[2] A. Alwiyah and S. Sayyida, "Penerapan E-Learning untuk Meningkatkan Inovasi Creativepreneur Mahasiswa," ADI Bisnis Digit. Interdisiplin J., vol. 1, no. 1, pp. 35-40, 2020.

[3] T. Hariguna and T. Wahyuningsih, "Perancangan Ajri Learning Journal Center Menggunakan Tools Invision Untuk Mewujudkan Creative Innovation Soft Skill," ADI Bisnis Digit. Interdisiplin J., vol. 1, no. 1, pp. 1-9, 2020.

[4] F. Alfiah, R. Sudarji, and D. T. Al Fatah, "Aplikasi Kriptografi Dengan Menggunakan Algoritma Elgamal Berbasis Java Desktop Pada Pt. Wahana Indo Trada Nissan Jatake," ADI Bisnis Digit. Interdisiplin J., vol. 1, no. 1, pp. 22-34, 2020.

[5] Sudaryono, U. Rahardja, and N. Lutfiani, "The Strategy of Improving Project Management Using Indicator Measurement Factor Analysis (IMF) Method," in Journal of Physics: Conference Series, 2020, vol. 1477, no. 3, doi: 10.1088/1742-6596/1477/3/032023.

[6] H. T. Sukmana, "Prototyping ITSDI Journal Center Menggunakan Tools Invision Untuk Mewujudkan Creative Innovation Soft Skill Di Era Industri 4.0," ADI Bisnis Digit. Interdisiplin J., vol. 1, no. 1, pp. 56-69, 2020.

[7] B. S. Riza, "Blockchain Dalam Pendidikan: Lapisan Logis di Bawahnya," ADI Bisnis Digit. Interdisiplin J., vol. 1, no. 1, pp. 41-47, 2020.

[8] P. Edastama, N. Lutfiani, Q. Aini, S. Purnama, and I. Y. Annisa, "Blockchain Encryption on Student Academic Transcripts using a Smart Contract," J. Educ. Sci. Technol., 2021.

[9] U. Rahardja, N. Lutfiani, and H. L. Juniar, "Scientific Publication Management Transformation In Disruption Era," Aptisi Trans. Manag., vol. 3, no. 2, pp. 109-118, 2019.

[10] P. O. A. Sunarya and N. Lutfiani, "Analisis Sistem Sertifikasi Profesi Untuk Pengembangan Kompetensi Mahasiswa," ADI Bisnis Digit. Interdisiplin J., vol. 1, no. 1, pp. 70-77, 2020.

[11] U. Rahardja, N. Lutfiani, and A. Yolandari, "Penerapan Viewboard Informatif Pada Asosiasi Perguruan Tinggi Swasta Indonesia Dalam Era Industri 4.0," Technomedia J., vol. 3, no. 2, pp. 224-234, 2019, doi: 10.33050/tmj.v3i2.738.

[12] Z. Fauziah, H. Latifah, U. Rahardja, N. Lutfiani, and A. Mardiansyah, "Designing Student Attendance Information Systems Web-Based," Aptisi Trans. Technopreneursh., vol. 3, no. 1, pp. 23-31, 2021.

[13] A. I. L. Wibowo, A. D. Putra, M. S. Dewi, and D. O. Radianto, "Differences In Intrinsic Value With Stock Market Prices Using The Price Earning Ratio (Per) Approach As An Investment Decision Making Indicator (Case Study Of Manufacturing Companies In Indonesia Period 2016-2017)," Aptisi Trans. Technopreneursh., vol. 1, no. 1, pp. 82-92, 2019.

[14] M. Zarlis, E. P. Harahap, and L. N. Husna, "Test Appraisal System Application Based on YII Framework as Media Input Student Value Final Project and Thesis Session at Higher Education," Aptisi Trans. Technopreneursh., vol. 1, no. 1, pp. 73-81, Mar. 2019, doi: 10.34306/att.v1i1.31.

[15] Y. Lin and R. Li, "Real-time traffic accidents post-impact prediction: Based on crowdsourcing data," Accid. Anal. Prev., vol. 145, p. 105696, 2020.

[16] M. B. Djatmiko, A. Husain, G. Maulani, and L. Nirmalasari, "Analyze and Record a Series of Corporate Sales Transactions On Web Based Accounting Online System," Aptisi Trans. Manag., vol. 1, no. 2, pp. 103-115, 2017.

[17] Sudaryono, N. Lutfiani, Suseno, and Q. Aini, "Empirical Study of Research Performance Leading to Education 4.0 using the iLearning Method," Int. J. Adv. Trends Comput. Sci. Eng., vol. 8, no. 1.5, pp. 264-268, Nov. 2019, doi: 10.30534/ijatcse/2019/4681.52019.

[18] M. A. Mumen, F. P. Oganda, N. Lutfiani, and I. Handayani, "Implementation of OJS Based iJC Media E-Journal System at University of Pramita Indonesia," Aptisi Trans. Manag., vol. 4, no. 2, pp. 168-177, 2020.

[19] S. Sudaryono, L. Sunarya, and G. Maulani, "Facility for Customizing Transaction Forms on Master Data Using an Online Accounting System Web For Work Efficiency Company," Aptisi Trans. Manag., vol. 1, no. 1, pp. 17-23, 2017.

N. Nawindah and L. Fajarita, "Peningkatan Sumber Daya Manusia Melalui Pembuatan Blog Bagi Siswa Pusat Kegiatan Belajar Masyarakat," ADI Pengabdi. Kpd. Masy., vol. 
1 , no. 1 , pp. 87-90, 2020.

[20] A. Qanita, M. F. Fadhlillah, and A. Supriyana, "Analysis of Structural Equation Modeling as a Measuring Tool for Educational Management Research," Aptisi

Trans. Manag., vol.2, no. 2, pp. 129-139, 2018.

[21] P. Edastama, "The Importance of Maslahah Orientation in Sharia Institutions," Aptisi Trans. Manag., vol. 5, no. 2, pp. 180-190, 2021.

[22] W. Winarno, Y. Muhtadi, and M. A. Aldiya, "Application of Learning Management Using Non-test Instrument to Improve the Quality of Education," Aptisi Trans. Manag., vol. 3, no. 1, pp. 46-56, 2019.

[23] U. Rahardja, A. Moeins, and N. Lutfiani, "Leadership, competency, working motivation and paerformance of high private education lecturer with institution accreditation B: Area kopertis IV Banten province," Man India, vol. 97, no. 24, pp. 179-192, 2017.

[24] M. F. Wahyutama and N. Natasyah, "Perancangan Sistem Informasi Platform Pencarian Kerja Pada PT. Wira Karya Indonesia," ADI Bisnis Digit. Interdisiplin J., vol. 1, no. 2, pp. 46-59, 2020.

[25] Q. Aini, U. Rahardja, and T. Hariguna, "The antecedent of perceived value to determine of student continuance intention and student participate adoption of ilearning," Procedia Comput. Sci., vol. 161, pp. 242-249, 2019, doi: 10.1016/j.procs.2019.11.120.

[26] U. Rahardja, S. Sudaryono, N. P. L. Santoso, A. Faturahman, and Q. Aini, "Covid-19: Digital Signature Impact on Higher Education Motivation Performance," Int. J. Artif. Intell. Res., vol. 4, no. 1, May 2020, doi: 10.29099/ijair.v4i1.171.

[27] I. Faridah, F. R. Sari, T. Wahyuningsih, F. P. Oganda, and U. Rahardja, "Effect Digital Learning on Student Motivation during Covid-19," in 2020 8th International Conference on Cyber and IT Service Management (CITSM), 2020, pp. 1-5.

[28] F. P. Oganda, "Pemanfaatan Sistem IJC (iLearning Journal Center) Sebagai Media E Journal Pada Perguruan Tinggi Dan Asosiasi," CSRID (Computer Sci. Res. Its Dev. Journal), vol. 11, no. 1, pp. 23-33, 2021.

[29] S. Kosasi, "Karakteristik Blockchain Teknologi Dalam Pengembangan Edukasi," ADI Bisnis Digit. Interdisiplin J., vol. 1, no. 1, pp. 87-94, 2020.

[30] R. B. Putra, F. Yeni, H. Fitri, and D. J. Melta, "The Effect Of Board Of Commissioners Ethnic, Family Ownership And The Age Of The Company Towards The Performance Of The Company LQ45 Company Listed In Indonesia Stock Exchange," ADI J. Recent Innov., vol. 1, no. 2 Maret, pp. 85-92, 2020.

[31] R. Rojali and D. I. Sari, "Relationship Of Individual Characteristics, Physical Home Environment And Behavior With The Incidence Of Pulmonary Tb In Cijoro Pasir Village, Muara Village East Ciujung And West Rangkasbitung Village, Rangkasbitung Subdistrict, Lebak Regency 2019," ADI J. Recent Innov., vol. 1, no. 2, pp. 167-179, 2020. 